\title{
Research Advances in Tourism-Landscape Interrelations: An Editorial
}

\author{
Theano S. Terkenli (1)
}

Citation: Terkenli, T.S. Research Advances in Tourism-Landscape Interrelations: An Editorial. Land 2021, 10, 944. https://doi.org/ 10.3390/land10090944

Received: 12 August 2021

Accepted: 30 August 2021

Published: 8 September 2021

Publisher's Note: MDPI stays neutral with regard to jurisdictional claims in published maps and institutional affiliations.

Copyright: (C) 2021 by the author. Licensee MDPI, Basel, Switzerland. This article is an open access article distributed under the terms and conditions of the Creative Commons Attribution (CC BY) license (https:// creativecommons.org/licenses/by/ $4.0 /)$.
Department of Geography, University of the Aegean, University Hill, 81100 Mytiline, Greece; t.terkenli@aegean.gr

The significance of the landscape to a variety of experiences that are sought or unfold at a visited destination is well established and considered paramount to the study of tourism [1,2]. Landscape is central to sightseeing and tourism; without landscape there may not be tourism, and, by definition, no landscape could be considered such without its viewer/observer. This interdependence is also reflected in the European Landscape Convention, whereby landscape is 'an area, as perceived by people [including visitors], whose character is the result of the action and interaction of natural and/or human factors' (Chapter 1, Article 1, p. 9) [3]. Landscape is key to the development, marketing/promotion, and consumption of tourism destinations, and to triggering and sustaining tourism markets, and enticing tourist dreams, fantasies, and behaviors. From 'sight-seeing' practices-at the basis of all tourism activities - all the way up to the overall spatial planning and management of a destination for tourism development, indeed, all types of landscapes and places (whether spectacular or ordinary) may potentially hold interest for some types of visitors for the purposes of consumption of goods, services, activities, experiences, etc. [4]. Moreover, a long series of time-place-culture contingent tourist/visitor services and experiences are provided by landscapes, i.e., pleasure, change, relaxation, excitement, education, inspiration, well-being, etc. [5,6].

Nonetheless, the intertwined relationship between tourism and landscape comes with a series of costs and benefits within the context of tourism landscapes. Landscapes of tourism reflect and stage recreational trends, multifunctional livelihood systems, conflicts and opportunities for employment and income generation, as well as for human, cultural, and natural resource management and use [4]. Such landscapes are increasingly coming into the foreground of current debates about the future of the planet, in conjunction with various human and environmental crises (e.g., economic depression, climatic change, and the COVID-19 pandemic), which offer significant opportunities but also carry a serious bearing on the realms of both tourism and landscape. One positive trend in this direction is the current enormous proliferation of a broad range of alternative and special interest/ purpose forms of tourism/leisure, variably (and, often, intricately) connected to visited landscapes. The main goals of such endeavors tend to be increasingly compatible with sustainable/'green' development for the landscape, for local societies, and for tourism, while catering to a variety of broadly accessible tourism/leisure pursuits and activities [4]. Nonetheless, rising rates and globalizing patterns of mobility and consumption continue to require renewed and more in-depth scientific investigation into the sites and attractions sought by visitors and to the role of landscape in visitor experiences [1].

At the outset of any such endeavor, it should be taken into consideration that significant confusion exists in scholarly tourism literature around the terms tourist vs. tourism in conjunction with the concept of landscape [6,7]. The term 'tourism landscape' is intended to refer to the processes through which a landscape, activity, development, and so forth is shaped to serve the purposes of tourism (also, i.e., 'landscapes of tourism'). The term 'tourist landscape' indicates the ways, reasons, and processes in or through which such landscapes are substantiated and/or appropriated via the phenomenon of tourism. In other words, the term 'tourism landscapes' implies the ways in which these landscapes are 
produced, whereas 'tourist landscapes' rather implies the ways in which these landscapes are consumed [6].

The interface between these two broad and interrelated areas of scientific study, tourism and landscape, has lately elicited a variegated body of research in terms of its nature, focus, and approach—often consciously signaling multiple and shifting points of view in the context of leisure economy production and consumption [1,8]. Nevertheless, there is, as yet, no comprehensive and cohesive conceptual/theoretical framework to support this increasingly interdisciplinary body of work. However, interest in the study of the landscapes of tourism and tourism itself has been growing, especially in the last decade, as reflected in the increased number of publications and research questions addressed to this area of study $[6,7,9,10]$. Many challenges are involved in this task, and much remains to be understood and ascertained as the landscape and tourism - two highly complex and multifaceted scientific areas-come together in a variety of ways across time, space, and culture. The latter constitutes the objective of this Special Issue, which aims to enhance the interdisciplinary scientific dialogue on these issues and challenges, while highlighting their range and significance for tourism and the landscape, in terms of theory, empirical practice, approach, policy, ethics, and future prospects.

This Special Issue contains 16 contemporary scientific approaches to the touristlandscape relationship, covering the entire spectrum of scholarly advances. The contributions come from and/or represent applications from a series of countries, such as Spain, the Netherlands, China, Slovakia, Poland, Japan, and Italy.

Acknowledging the significant links and synergies between the landscape and tourism, Heslinga, Groote, and Vanclay [11] use the case study of Terschelling, a Dutch island in the UNESCO World Heritage Wadden Sea, and an important tourism destination renowned for its outstanding landscapes, to provide overarching recommendations for the improvement of decision making toward regional resiliency. They suggest that tourism-landscape synergies are preconditions for building such resiliency, and that such synergies may be achieved through integrated policies aimed at joint interactions with the inclusion of all pertinent stakeholders, co-creating a clear and shared vision of the future in the context of the historical institutional regional framework, daring to experiment but flexible in terms of local implementation.

In order to understand the evolutionary processes taking place in coastal areas of post-communism tourism destinations, Bal and Czalczynska-Podolska [12] analyze both internal and external drivers of tourism-induced historical change in the cultural landscape of the Baltic coastline of Poland. On the basis of transformations of nature and forms of recreation, they identify four distinct stages in the shaping of spatial/landscape elements in such seaside resorts and relevant recreational architecture: (a) formation-elite resorts era (early 19th-20th centuries); (b) regionalism — national resort development (1918-1939); (c) socialization—resorts for working masses (1945-1989); and (d) pluralism—egalitarian health resort development (since 1989). The study contributes to the discussion of commonly known models of tourism development, with the view of supporting the sustainable planning and development of such coastal tourism destinations.

Chakraborty [13] describes the complex interrelationship developing between emerging patterns of mountain tourism and the landscape in the Kamikochi Valley, situated in the Northern Japan Alps, and assesses sustainable tourism challenges, primarily from a landscape point of view and secondarily from a tourist point of view. The study, part of a two-year-long ongoing research project, reveals that the intensity of visitation results in direct pressures on the landscape and wildlife, as well as more subtle pressures in the form of ongoing infrastructure buildup and modification of key geomorphic processes. It also reveals a general demand for such information from tourists, who tend to have minimal knowledge of such pressures and impacts. Further, it underlines that the overarching challenge to managing tourism in a sustainable manner remains understanding, appreciating, and proactively conserving the biophysical mechanisms of such places. 
A two-way perspective is also employed for the analysis of the mining tourism landscape in Cartagena-La Unión, Spain, by approaching the landscape as digital content and as a smart tourism destination. The emphasis of this research by Pardo Abad and Fernández Álvarez [14] is on eliciting the potential of different mining areas for tourism development, while illustrating the role of new information and communication technologies (ICTs) in such development. After laying out the scenic and aesthetic variables of mining landscapes, the researchers investigate the extent to which the landscape is used for tourism purposes as well as its presence on the Internet and its digitization for tourism purposes. Their work features the ways that such an area can be regarded as a landscape suitable for the smart promotion of tourism, through the application of innovative digital techniques facilitating and disseminating tourism and efficient resource management. They further show how such ICTs may generate a large amount of digital content about landscapes and their aesthetic characteristics, with interesting information for tourists about the most significant natural and cultural attractions of the destination.

The role of the landscape in both the sustainable territorial management of natural resources and the socio-economic development of marginal rural areas is the basis of the study by Bonadonna, Rostagno, and Beltramo in the northwest of Italy [15]. The main tenet of the researchers is that land consolidation associations (LCAs) are a useful tool/means of territorial management, as LCAs aim to improve the link between the landscape and tourism in holistic, participatory, and integrated ways. Accordingly, the researchers proceed to compare the different LCAs operating in the Piemonte region, in terms of their differences and similarities, for purposes of tourism development improvement. The study showcases this approach as a useful tool in the management of fragmented territories for rural communities, aiming to stimulate and revitalize their ability to produce environmental, economic, and social value, ensuring territorial sustainability and tourism-landscape synergies.

Although the latter synergies between landscape and tourism have proven to be fertile ground for research that has been broad and diverse in nature, subject matter, and methodology, in recent years, there has not been adequate organization and theorization of this interdisciplinary subject matter. In this regard, the article by Jiménez-García, RuizChico, and Peña-Sánchez maps this compound research area, using bibliometric techniques (VOSviewer and Science Mapping Analysis Software Tool (SciMAT) software) [9], and presents the evolution of this scientific field, including the main concepts and approaches to their study but, also, work themes that have been and continue to be fundamental to the construction of the field. They conclude that, in the past decade, (a) the subject of the tourism-landscape interrelationship has been analyzed by a large number of authors, but few groups have specialized in it; and (b) this increase in the number of publications has been reflected in the increase of research topics dealing with landscape and tourism. They also signal significant shifts away from research themes that have been the center of interest in the past toward new emerging ones which seem to carry the field in the direction of more dynamic and further developed areas of future research.

The next study by Cheng, Gao, Shao, and Iqbal [16] delves into the contribution of the landscape to campus tourism, in relation to the Wangjiang Campus of Sichuan University in China. In order to decipher the comprehensive influence of specific natural and humaninduced environmental aspects on campus landscapes of three multi-scalar perspectives (point, line, and plane), the study employs different research themes comprising of (i) landscapes of buildings and vegetation, (ii) color landscapes, (iii) landscapes of campus space utilization, and (iv) thermal landscapes. The outcomes of this study advocate for the comprehensive consideration of the characteristics of different campus landscapes at different scales as conducive to the design, planning, and experience of campus tourism, which may serve as a reference for the development of university campus tourism at other locations.

A further study by Bal and Czalczynska-Podolska [17] on the coastline of Western Pomerania, Poland, addresses the negative potential impact of tourism development on the cultural landscape of seaside resorts and provides recommendations for landscape shaping, management, and conservation. The authors evaluate 11 development projects (including 
a range of hotels, luxury residential buildings, and hotel suites) built between 2009 and 2020 through: (a) an assessment of each project's architecture-and-landscape integration, using four groups of evaluation criteria (aesthetic, socio-cultural, functional, and locational factors); (b) a historical interpretative study (iconology, iconography, historiography), and (c) an examination of architecture-and-landscape integration using a pre-prepared evaluation form. This study demonstrates that it is possible to identify detrimental impacts of tourism on destination landscapes and offers recommendations for protective measures, in order to ensure that new developments at these destinations conform to landscape/spatial structures and characteristics in line with the area's original cultural profile and identity.

In China, Luo and Chiou [18] propose a hierarchical framework for the development of cultural tourism attractiveness in Chinese historic districts, combining 2 aspects (the physical environmental and the cultural/natural environmental) and 5 criteria (including landscape morphology and tourism infrastructure), along with 21 elements of the Chinese historic districts, in order to support these districts in terms of cultural tourism development while taking into account landscape conservation, district management, and living convenience. The contribution of this work lies in the establishment of the hierarchical framework outlining the components of cultural tourism attractiveness for Chinese historic districts in a systematic way. This framework may serve as a theoretical reference in future efforts toward the sustainable and coordinated planning of cultural tourism attractiveness, while supporting landscape conservation in Chinese historic districts.

Another study of the interrelationship between tourism and mountainous landscapes is presented by Abellán and García Martínez, purporting to evaluate landscape as a heritage and tourism resource, focusing on its capacity to reactivate depressed rural areas of inland Spain (midmountain areas in the southeast of the autonomous region of Castilla-La Mancha), according to the opinions and perceptions of its visitors, collected through a field survey [19]. The study identifies processes of socio-territorial transformation which have led to the expansion of the area's tertiary sector due to a rise in tourism, an activity closely linked to the characteristics of the territory, its landscape, and the ecosystem resources (constituting its primary attractions as a tourist destination). The landscape and its features emerge as the primary tourist attraction in these mountain areas and as a key element of the tourism system from a resource perspective, thus highlighting the need for landscape education programs aimed at preserving the elements of these resources.

Another proposal, also based in China, comes from Li, Zhou, and Zhang [20] in the form of a compilation of a set of strategies for landscape planning in peri-urban rural tourism, with a view toward establishing the local natural and cultural character of the landscape for the purposes of integrating and encapsulating it in such tourism development. In order to contribute to a better understanding of comprehensive landscape planning, integrating natural and cultural dimensions in peri-urban villages, this research compares and critically discusses the relevant strategies of two such Chinese villages (Heshu village and Pu'an village in the Yangtze River Delta) in terms of their integration of natural and cultural elements forming landscapes with a distinctive local character, aiming to boost tourism development. While differences emerge between the two case studies in the latter regard, the overall conclusion is that it is essential to consider the interests of both locals and tourists in the process of identifying, preserving, and enhancing the locality of rural peri-urban landscapes.

The study by Terkenli, Skowronek, and Georgoula [6] goes a step further in investigating the relationship between landscape and tourism, in a comprehensive and integrated way, on the basis of a broad questionnaire survey of European landscape and tourism experts. The latter's notions and perceptions of the reciprocal relationship between the landscape and tourism are analyzed and assessed regarding: (a) understandings and visions of future optimization of the relationship tourism-landscape, (b) their conceptualizations of 'landscapes of tourism', and (c) their assessments of the prospects (opportunities) and challenges (threats) of the tourism-landscape relationship, both for the tourism industry and the local societies. Besides the emergence of a definition for 'landscapes of tourism', the 
findings point to the high significance of the tourism-landscape relationship, vis-à-vis both its positive and negative aspects, but reveal an inclination toward its negative aspects. The study also exhibits that the experts express crucial socio-environmental concerns regarding the tourism-landscape interrelationship but support the principles of sustainability, locality, and participatory governance, while calling for appropriate future governmental planning.

Another very valuable study focusing on the theorization of the tourism-landscape interrelationship comes from Meneghello [21], who conducts a bibliographic analysis of scholarly contributions to the nexus and conceptualization of 'tourist landscapes' and other relevant terms, in order to map different ways of defining and understanding this complex interrelationship as it emerges from the main research areas. The findings of the study enrich the scientific reflections on this relationship, providing new definitional contributions and a conceptual framework able to influence coherently both theory and practice. The implemented bibliometric analysis brings up three main research topics: planning and governance, situated spatial-social-symbolic interrelations, and impact evaluation. The study unveils a recent increase in the awareness of terminological issues, despite a more general lack of attention to the actual use of specific terms. It also illustrates reflections on the relational dimension of landscape, as the latter have been maturing in tourism studies from around 2010, but have only very recently begun to be consolidated and increasingly guide pertinent theoretical investigations.

The next article, by Wang and Marafa [22], complements previous approaches to the tourism-landscape relationship, by exploring the production, reproduction, and development of tourist landscape imaginaries-and, specifically, agricultural cultural heritage sites-in a case study of the Honghe Hani Rice Terraces in China. For this purpose, and based on theories of social and tourism imaginaries, the authors conduct content analysis on tourist discourses and images on social media, as well as in-depth interviews with stakeholders and participant observations. A gap between tourism imaginaries and the actual Hani landscape becomes apparent, with the latter being imagined as a stereotyped terraced view/prospect staged for gazing, as dictated by the tourism industry, but disconnected from the realities of local community life and environmental predicaments. In addition to emphasizing the need for the formulation of appropriate resource management policies to protect the physical landscape, the findings advocate for the preservation of the cultural significance of the landscape and the empowerment of local communities, toward the promotion of knowledge- and community-based tourism.

Relationships between the scenic beauty of geosites, their scientific value, and tourists' geoscientific knowledge is investigated by Tessema, Poesen, Verstraeten, and Van Rompaey, in a large survey of 34 geosites in southeastern Spain [23]. The survey enlisted 29 respondents with a geoscience background who visited the 34 geosites, 43 respondents with a geoscience background who did not visit the geosites, and 104 respondents with no geoscience background who also did not visit the geosites. The findings unveil a significant relationship between the geosites' scenic beauty and their scientific value. Furthermore, the significance of this relationship seems to increase with the geoscientific knowledge of the respondent. These findings have important implications for geoconservation, geoheritage management/protection, and sustainable geotourism development, as more geoscience education and geointerpretation seem to facilitate people's appreciation of the geosites scenic beauty. Furthermore, the study shows that the presence of viewpoints seems to be an important factor in scenic beauty rating and, more generally, that geosites combining certain features are more interesting to all types of respondents, irrespective of the latter's geoscientific background.

Finally, from the Slovak Republic, is a study on the life cycle of landscape transformationboth positive and negative- through tourism, undertaken in six very diverse localities. Oremusová, Nemčíková, and Krogmann [24] rely on the Drivers-Pressures-State-ImpactResponse (DPSIR) model for their integrated environmental assessment of such transformation and on the methodology of the tourism destination life cycle, using integrated sustainable development indicators. This contribution highlights the transformation pro- 
cesses leading to the creation of a tourist landscape and critically evaluates their effects on the overall environment and land uses of the selected sites. The authors also present possibilities of further directions in sustainable tourism planning and development, while pointing out related benefits and risks, and taking into consideration the landscape character, identity, and future visions of the territory.

We hope that this collective effort will play a role in promoting and advancing the increasingly growing and expanding interdisciplinary area where landscape and tourism come together. This task will have been successful only if it is seen to contribute to relevant theory, methodology, and empirical knowledge, offering further research insights and questions that may open up even broader possibilities for scientific exploration and sustainable options for tourism and landscape planning, management, marketing, and appropriation. Such prospects are especially relevant, valuable, and timely-even urgent-in today's context of a fast-changing world and constitute an excellent opportunity for humanity's response to crises and conflicts that lie at the heart of our survival and well-being.

Funding: This research received no external funding.

Acknowledgments: I am grateful to the MDPI Land team of academic editors and reviewers for our collaboration in ensuring this Special Issue's academic excellence, during the whole process of its production.

Conflicts of Interest: The author declares no conflict of interest.

\section{References}

1. Cartier, C.; Lew, A.A. (Eds.) Seductions of Place: Geographical Perspectives on Globalization and Touristed Landscapes; Routledge: Abingdon, UK, 2005.

2. Terkenli, T.S. Landscapes of tourism. In The Wiley-Blackwell Companion to Tourism; Lew, A.A., Hall, C.M., Williams, A.M., Eds.; John Wiley \& Sons: New York, NY, USA, 2014.

3. Council of Europe. European Landscape Convention. 2000. Available online: https:/ /rm.coe.int/16802f80c6 (accessed on 29 April 2021).

4. Encyclopedia of Tourism Management and Marketing. In Encyclopedia of Tourism Management and Marketing; Edward Elgar Publishing: Cheltenham, UK, 2021.

5. Crouch, D. Leisure/Tourism Geographies: Practices and Geographical Knowledge; Routledge: Abingdon, UK, 1999.

6. Terkenli, T.; Skowronek, E.; Georgoula, V. Landscape and Tourism: European Expert Views on an Intricate Relationship. Land 2021, 10, 327. [CrossRef]

7. Skowronek, E.; Tucki, A.; Huijbens, E.H.; Jóźwik, M.J. What is the tourist landscape? Aspects and features of the concept. Acta Geogr. Slov. 2018, 58, 73-85. [CrossRef]

8. Terkenli, T.S.; d'Hauteserre, A.-M. (Eds.) Landscapes of a New Cultural Economy of Space; Springer: Dordrecht, The Netherlands, 2006.

9. Jiménez-García, M.; Ruiz-Chico, J.; Peña-Sánchez, A.R. Landscape and Tourism: Evolution of Research Topics. Land 2020, 9 , 488. [CrossRef]

10. Gkoltsiou, A.; Terkenli, T.S.; Koukoulas, S. Landscape indicators for the evaluation of tourist landscape structure. Int. J. Sustain. Dev. World Ecol. 2013, 20, 461-475. [CrossRef]

11. Heslinga, J.; Groote, P.; Vanclay, F. Towards Resilient Regions: Policy Recommendations for Stimulating Synergy between Tourism and Landscape. Land 2020, 9, 44. [CrossRef]

12. Bal, W.; Czalczynska-Podolska, M. The Stages of the Cultural Landscape Transformation of Seaside Resorts in Poland against the Background of the Evolving Nature of Tourism. Land 2020, 9, 55. [CrossRef]

13. Chakraborty, A. Emerging Patterns of Mountain Tourism in a Dynamic Landscape: Insights from Kamikochi Valley in Japan. Land 2020, 9, 103. [CrossRef]

14. Abad, C.J.P.; Álvarez, J.F. Landscape as Digital Content and a Smart Tourism Resource in the Mining Area of Cartagena-La Unión (Spain). Land 2020, 9, 112. [CrossRef]

15. Bonadonna, A.; Rostagno, A.; Beltramo, R. Improving the Landscape and Tourism in Marginal Areas: The Case of Land Consolidation Associations in the North-West of Italy. Land 2020, 9, 175. [CrossRef]

16. Cheng, D.; Gao, C.; Shao, T.; Iqbal, J. A Landscape Study of Sichuan University (Wangiang Campus) from the Perspective of Campus Tourism. Land 2020, 9, 499. [CrossRef]

17. Bal, W.; Czalczynska-Podolska, M. Assessing Architecture-and-Landscape Integration as a Basis for Evaluating the Impact of Construction Projects on the Cultural Landscape of Tourist Seaside Resorts. Land 2020, 10, 17. [CrossRef]

18. Luo, H.; Chiou, B.-S. Framing the Hierarchy of Cultural Tourism Attractiveness of Chinese Historic Districts under the Premise of Landscape Conservation. Land 2021, 10, 216. [CrossRef]

19. Abellán, F.; Martínez, C.G. Landscape and Tourism as Tools for Local Development in Mid-Mountain Rural Areas in the Southeast of Spain (Castilla-La Mancha). Land 2021, 10, 221. [CrossRef] 
20. Li, W.; Zhou, Y.; Zhang, Z. Strategies of Landscape Planning in Peri-Urban Rural Tourism: A Comparison between Two Villages in China. Land 2021, 10, 277. [CrossRef]

21. Meneghello, S. The Tourism-Landscape Nexus: Assessment and Insights from a Bibliographic Analysis. Land $2021,10,417$. [CrossRef]

22. Wang, Z; Marafa, L. Tourism Imaginary and Landscape at Heritage Site: A Case in Honghe Hani Rice Terraces, China. Land 2021, 10, 439. [CrossRef]

23. Tessema, G.; Poesen, J.; Verstraeten, G.; Van Rompaey, A.; van der Borg, J. The Scenic Beauty of Geosites and Its Relation to Their Scientific Value and Geoscience Knowledge of Tourists: A Case Study from Southeastern Spain. Land 2021, 10, 460. [CrossRef]

24. Oremusová, D.; Nemčíková, M.; Krogmann, A. Transformation of the Landscape in the Conditions of the Slovak Republic for Tourism. Land 2021, 10, 464. [CrossRef] 